\title{
Antioxidant activity of oily extract obtained from Lippia origanoides improves the quality of bovine embryos produced in vitro
}

\author{
[Atividade antioxidante de óleo essencial obtido de Lippia origanoides melhora a qualidade de \\ embriões bovinos produzidos in vitro] \\ N.V. Sollecito ${ }^{1}$, E.C.M. Pereira ${ }^{2}$, J.G.V. Grázia ${ }^{1}$, B.P. Neves ${ }^{1}$, B.V.R. Couto ${ }^{1}$, \\ V.B. Andrade ${ }^{1}$, M.S. Miranda ${ }^{3}$, J.K.R. Silva ${ }^{3}$, A.M. Borges ${ }^{4}$ \\ ${ }^{1}$ Aluno de pós-graduação - Universidade Federal de Minas Gerais - Belo Horizonte, MG \\ ${ }^{2}$ Universidade Federal de Uberlândia - Uberlândia, MG \\ ${ }^{3}$ Universidade Federal do Pará - Belém, PA \\ ${ }^{4}$ Universidade Federal de Minas Gerais - Belo Horizonte, MG
}

\begin{abstract}
The aim of this study was to evaluate the supplementation of embryo culture medium with antioxidant obtained from oily extract of Lippia origanoides on in vitro blastocyst development and quality. Oocytes collected from slaughterhouse ovaries were matured and fertilized in vitro following standard laboratory procedures. Zygotes were cultured in SOF medium supplemented according to the following treatments: T1 embryo culture medium without antioxidant supplementation; T2) $50 \mu \mathrm{M} / \mathrm{mL}$ Cysteamine; T3) $2.5 \mu \mathrm{g} / \mathrm{mL}$; T4) $5.0 \mu \mathrm{g} / \mathrm{mL}$ and $\mathrm{T} 5) 10.0 \mu \mathrm{g} / \mathrm{mL}$ of antioxidant obtained from oily extract of Lippia origanoides. On the seventh day of culture, the blastocysts were fixed and evaluated for apoptosis rates, number of total cell and inner cell mass cells by means of the TUNEL Test. The use of antioxidants during cultivation did not increase $(\mathrm{P}>0.05)$ the final blastocyst production rate. The treatments $\mathrm{T} 2, \mathrm{~T} 3$, $\mathrm{T} 4$ and $\mathrm{T} 5$ had the lowest $(\mathrm{P}<0.05)$ apoptotic indexes $(4.5 \pm 1.1 \%, 8.4 \pm 2.5 \%, 3.4 \pm 1.1 \%$ and $5.5 \pm 0.9 \%$, respectively) when compared to T1 treatment $(10.0 \pm 1.4 \%)$. The number of inner cell mass did not differ (P> 0.05) among embryos from different treatments. The addition of antioxidant obtained from oily extract of Lippia origanoides reduces the apoptosis rate and improves the quality without increasing the total in vitro production of bovine embryos.
\end{abstract}

Keywords: antioxidants, apoptosis, Lippia origanoides, in vitro embryo production

\section{RESUMO}

O objetivo desse estudo foi avaliar a suplementação de meio de cultura de embriões com antioxidante obtido do extrato oleoso da Lippia origanoides no desenvolvimento e na qualidade de blastocistos produzidos in vitro. Oócitos coletados de ovários de matadouros foram maturados e fertilizados in vitro segundo procedimento laboratorial padrão. Zigotos foram cultivados em meio SOF suplementado de acordo com os seguintes tratamentos: T1) meio de cultivo embrionário sem suplementação antioxidantes; T2) $50 \mu \mathrm{M} / \mathrm{mL}$ Cisteamina; T3) 2,5 $\mathrm{g} / \mathrm{mL}$; T4) $5,0 \mu \mathrm{g} / \mathrm{mL}$ e T5) $10,0 \mu \mathrm{g} / \mathrm{mL}$ do antioxidante obtido do extrato oleoso de Lippia origanoides. No sétimo dia de cultivo, os blastocistos foram fixados e avaliados para taxa de apoptose, número total de células e massa celular interna através do teste TUNEL. O uso de antioxidantes durante cultivo não aumentou $(P>0,05)$ a taxa de produção final de blastócitos. Os tratamentos T2, T3, T4 e T5 tiverem menor índice apoptótico ( $p>0,05-4,5 \pm 1,1 \%, 8,4 \pm 2,5 \%, 3,4 \pm 1,1 \%$ e $5,5 \pm 0,9 \%$, respectivamente) quando comparados a $T 2(10,0 \pm 1,4 \%)$. $O$ valor de massa celular interna não diferenciou $(p>0,05)$ entre embriões de diferentes tratamentos. A adição de antioxidante obtido do extrato oleoso de Lippia origanoides reduziu a taxa de apoptose e melhorou a qualidade sem aumentar a produção in vitro de embriões bovinos.

Palavras-chave: antioxidantes, apoptose, Lippia origanoides, produção de embriões in vitro

Recebido em 2 de outubro de 2017

Aceito em 6 de dezembro de 2017

E-mail: nat.sol86@yahoo.com.br 


\section{INTRODUCTION}

The in vitro embryo production (IVEP) has been one of the most important tools for multiplication and acceleration of genetic gain in bovine herds (Loiola et al., 2014). Despite the improvements observed in recent years, this biotechnology still has limitations regarding to the blastocyst production rate and embryo freezing, mainly due to the composition of embryo culture media (Lonergan and Fair, 2008).

The in vitro culture conditions are affected by adverse agents, including reactive oxygen species (ROS) (Crocomo et al., 2012). The oxidative stress caused by the imbalance between the production and elimination of ROS acts on cell membranes and cytoplasm causing alterations in lipids, proteins and nucleic acids. It damages the embryos by means of mitochondrial modifications, blockage of embryonic development, depletion of ATP and apoptosis (Guérin et al., 2001).

To protect cells from the deleterious effects of excess ROS and to facilitate embryo development, culture media have been modified by the addition of antioxidants (Agarwal et al., 2005) obtained from different plant sources. In this context, a shrub native to Central America and northeastern South America, Lippia origanoides, has shown great potential for traditional medicine because of its bioactive principles used to treat different diseases (Soares and Tavares-Dias, 2013). The oily extracted from this plant has antioxidant properties attributed to the action of thymol and carvacrol, elements found in its composition and responsible for increasing the concentrations of glutathione (Teixeira et al., 2014). For this reason, it has been used in in vitro production of bovine embryos.

In view of the reduced cellular apoptosis rate related to the antioxidant property of oily extract of Lippia origanoides, previously tested only in in vitro maturation of bovine oocytes (Pereira, 2015), and considering that high apoptosis rate compromise the production of blastocysts and embryo viability (Madox-Hyttell et al., 2003), the aim of this study was to evaluate the production and quality of bovine embryos produced in vitro with different concentrations of oily extract of Lippia origanoides in the embryo culture media.

\section{MATERIAL AND METHODS}

The trial was performed in accordance with the rules of the Ethics Committee on Animal Use CEUA/UFMG (protocol 339/2016). All reagents and media used were purchased from SigmaAldrich (St Louis, MO, USA).

The ovaries were obtained from slaughtered bovine females and transported in $0.9 \% \mathrm{NaCl}$ saline solution at $38^{\circ} \mathrm{C}$ within a maximum period of 4 hours after sampling, to the laboratory of in vitro bovine embryo production of the Veterinary School of the Federal University of Minas Gerais. Follicles of $2-8 \mathrm{~mm}$ were aspirated with $5 \mathrm{~mL}$ syringes coupled to $40 \times 12 \mathrm{~mm}$ needles and the contents were deposited in $50 \mathrm{~mL}$ Falcon Tubes for 10 minutes for sedimentation of follicular fluid.

The cumulus-oocyte complexes (COCs) were selected and washed in HEPES buffered TCM 199 medium supplemented with $22 \mu \mathrm{g} / \mathrm{mL}$ sodium pyruvate, $50 \mu \mathrm{g} / \mathrm{mL}$ amikacin sulfate and $10 \%$ fetal bovine serum (FBS). Oocytes with compact and non-expanded cumulus, with two or more layers of cells and homogeneous and intact cytoplasm were selected (Seneda et al., 2001). The in vitro maturation medium (IVM) of oocytes was composed of bicarbonate-buffered TCM-199 supplemented with $10 \%$ FBS + $22 \mu \mathrm{g} / \mathrm{mL}$ sodium pyruvate $+50 \mu \mathrm{g} / \mathrm{mL}$ amikacin sulfate $+5 \mu \mathrm{g} / \mathrm{mL} \mathrm{LH}+1 \mu \mathrm{g} / \mathrm{mL}$ FSH. After filtration of medium through a cellulose membrane, $10 \mu \mathrm{g} / \mathrm{mL}$ of estradiol and $2.5 \mu \mathrm{g} / \mathrm{mL}$ of oily extract of Lippia origanoides were added in all treatments described below. The COCs were regrouped in drops containing 10-15 oocytes and incubated in a culture oven (Thermo Scientific, USA) with a humid atmosphere at $5 \%$ $\mathrm{CO}_{2}, 38.5^{\circ} \mathrm{C}$ for $22-24$ hours counted from the beginning of follicular aspiration.

After the evaluation of the rate of expansion, in the in vitro fertilization (IVF), the semen from a Holstein bull was used and previously tested for in vitro embryo production. Sperm selection was performed using the Percoll gradient technique (45-90\%), described by Parrish et al. (1984). After centrifugation, the supernatant was removed and the spermatozoa was resuspended 
with $3 \mathrm{~mL}$ of TALP medium, and once more centrifuged at $250 \times \mathrm{xG}$ for 5 minutes. An insemination dose of $2 \times 10^{6}$ spermatozoids $/ \mathrm{mL}$ was used. The oocytes were transferred to $70 \mu \mathrm{L}$ drops of IFV medium and co-incubated with spermatozoa under mineral oil and in humidified atmosphere at $5 \% \mathrm{CO}_{2}, 38.5^{\circ} \mathrm{C}$ for $16-20$ hours.

In the in vitro culture (IVC), cumulus cells were removed by manual and successive pipetting, and the zygotes were allocated to one of the following treatments:

- Treatment 1 - SOF-m medium (Synthetic Oviduct Fluid modified) without antioxidant supplementation;

- Treatment 2 - SOF-m medium (modified) supplemented with $50 \mu \mathrm{M} / \mathrm{mL}$ of antioxidant Cysteamine, as standard antioxidant;

- Treatment 3 - SOF-m medium (modified) supplemented with $2.5 \mu \mathrm{g} / \mathrm{mL}$ of antioxidant obtained from oily extract of Lipia origanoides;

- Treatment 4 - SOF-m medium (modified) supplemented with $5.0 \mu \mathrm{g} / \mathrm{mL}$ of antioxidant obtained from oily extract of Lippia origanoides; - Treatment 5 - SOF-m medium (modified) supplemented with $10 \mu \mathrm{g} / \mathrm{mL}$ of antioxidant obtained from oily extract of Lippia origanoides.

Embryo culture was performed at $38.5^{\circ} \mathrm{C}$ in a moisture-saturated atmosphere of $5 \% \mathrm{CO}_{2}, 5 \%$ $\mathrm{O}_{2}$ and $90 \% \quad \mathrm{~N}_{2}$. After 72 hours postinsemination, the proportion of embryos that reached the 2-, 4- and 8-cell stages was evaluated to determine the cleavage rate (number of cleaved zygotes/total number of mature oocytes). At the end of the seventh day of culture (D7), the embryos were evaluated and properly classified according to their morphological aspect to determine the blastocyst rate (number of blastocysts/number of cultured oocytes). The embryos were fixed in $4 \%$ paraformaldehyde for the Terminal deoxynucleotidyl transferase (TUNEL) test.

To determine the apoptosis index, the DNA fragmentation in embryonic cells was evaluated by means of the TUNEL test. The cells were stained, and their nuclei became evident, thus enabling the counting of total intact and apoptotic cells. The procedures were based on the methodology described by Pereira (2010) for bovine embryos. The commercial kit Dead End Fluorimetric TUNEL System (Promega,
Madison, WI, USA) was used for the test. Blastocysts at different stages of development were washed in $100 \mu \mathrm{L}$ drops of phosphate saline solution (Nutricell®) supplemented with $0.1 \%$ Bovine Serum Albumin (BSA, Sigma). Subsequently, they were fixed in $4 \%$ paraformaldehyde, washed again and stored in cryotubes at $4{ }^{\circ} \mathrm{C}$ with saline solution plus $0.1 \%$ BSA. For the preparation of slides, the embryos were initially permeabilized by immersion in phosphate saline solution with $0.2 \%$ Triton $\mathrm{X}$ 100 and incubated in equilibration buffer $(180 \mu \mathrm{L})$ with a mixture of nucleotides $(20 \mu \mathrm{L})$, rTdT enzyme $(4 \mu \mathrm{L})$ and fluorescein-12-dUTP that is responsible for staining the fragmented DNA. The embryos remained for 1 hour at $37^{\circ} \mathrm{C}$ in a humid chamber covered with aluminum foil. In the negative control, the embryos were incubated in equilibration buffer without rTdT enzyme. In the positive control, the embryos were incubated in equilibration buffer containing the DNase enzyme $(2.7 \mathrm{U} / \mu \mathrm{L})$, responsible for promoting degradation of the DNA of embryonic cells, and with the enzyme fluorescein-12-dUTP.

In the next step, the embryos were transferred to dried and degreased slides stained with 4'6diamidino-2-phenylindole (DAPI) Vectashield (Vector Laboratories, Inc., Burlingame, USA). Subsequently, coverslips were applied. Embryonic cells (embryoblast, trophoblast, blastomeres) were labeled by DAPI (in blue) using a 460nm filter and the apoptotic cells were identified using a $520 \pm 20 \mathrm{~nm}$ fluorescein filter (green). The slides were observed on an epifluorescence microscope ( $\mathrm{Bx} 52$, Olympus, Washington, USA) and photographed using the Image-Pro Plus 4.5 software (Media Cybernectics, Silver Spring, USA).

The total number of intact and apoptotic cells, the identification of cells belonging to the inner cell mass (ICM) and verification of the relationship between ICM and total embryonic cells were analyzed using the Image $\mathrm{J}$ program (Version 1.42e, 2008), following the methodology of Iwasaki et al. (1990). The apoptotic index was calculated from the ratio of total cell number and number of cells containing apoptotic bodies (Kidson et al., 2004).

Data relative to rates of expansion, cleavage, blastocyst and in vitro bovine embryo production were previously analyzed for normality. Data 
were analyzed by ANOVA when normal, whereas the Kruskall-Wallis test was used to analyze the non-normal data. The evaluation of total cell number and apoptotic index was performed by the Shapiro-Wilk test to verify the normality of continuous variables. In the statistical analysis, the ANOVA (post-hoc Tukey) and Kruskall-Wallis tests were used at 5\% significance. The Version 17.0 of the SPSS software (SPSS Inc, Chicago, USA) was used for all analyzes.

\section{RESULTS AND DISCUSSION}

The in vitro production of bovine embryos according to the concentration of oily extract of Lippia origanoides is shown in Table 1. The addition of different concentrations of Lippia origanoides did not modify $(\mathrm{P}>0.05)$ the rates of expansion, cleavage, blastocyst and total in vitro production of bovine embryos among treatments.

Table 1. Rates (mean \pm SD) of expansion, cleavage, blastocyst and total in vitro production of bovine embryos according to the concentration of essential oil of Lippia origanoides in embryo culture medium

\begin{tabular}{ccccc}
\hline Treatment & $\mathrm{N}$ & $\begin{array}{c}\text { Expansion rate } \\
(\%)\end{array}$ & Cleavage rate $(\%)$ & Blastocyst rate $(\%)$ \\
\hline TI- 0 (Control) & 720 & $95.6 \pm 5.6$ & $61.0 \pm 21.6$ & $27.6 \pm 18.3$ \\
T2 - 50 $\mu \mathrm{M} / \mathrm{mL}$ Cysteamine & 720 & $93.2 \pm 16.8$ & $59.4 \pm 20.1$ & $22.2 \pm 12.7$ \\
T3- $2.5 \mu \mathrm{g} / \mathrm{mL}$ Lippia origanoides & 720 & $95.9 \pm 4.1$ & $55.9 \pm 22.8$ & $21.4 \pm 15.9$ \\
T4 - $5.0 \mu \mathrm{g} / \mathrm{mL}$ Lippia origanoides & 720 & $95.8 \pm 5.4$ & $57.2 \pm 23.8$ & $26.0 \pm 17.7$ \\
T5- $10.0 \mu \mathrm{g} / \mathrm{mL}$ Lippia origanoides & 720 & $95.9 \pm 4.8$ & $54.6 \pm 19.5$ & $20.6 \pm 13.2$ \\
\hline
\end{tabular}

In a study using similar concentrations of oily extract of Lippia origanoides, but only in in vitro maturation media of bovine oocytes, Pereira (2015) found rates of expansion, cleavage and blastocyst similar to those of the present study. Furthermore, there was no difference in variables between treatments, and the rates of embryo production remained within the expected pattern for the bovine species, as described by Feugang (2009). This result suggests that the supplementation with oily extract of Lippia origanoides in oocyte maturation and embryo culture media does not influence the rate of in vitro production of bovine embryos.

The blastocyst production rate in the culture medium containing $50 \mu \mathrm{M} / \mathrm{mL}$ cysteamine, a standard antioxidant in commercial laboratory protocols used as a positive control in the present study, was $22.2 \pm 12.7 \%$. This value is similar to the $29.1 \pm 2.7 \%$ of blastocysts in D7 found by Lojkic et al. (2012) for zygotes grown at the same concentration of cysteamine. A blastocyst rate of $24 \%$ was obtained by Merton et al. (2013) by adding $0.1 \mathrm{mM}$ cysteamine in oocyte maturation and in vitro culture media of bovine embryos. The positive action of cysteamine as an antioxidant results from the increase in glutathione synthesis through cysteine and, consequently, it has a beneficial effect on IVEP, increasing production and embryo quality (Zhou et al., 2008).

Several antioxidants have been studied by different research groups in in vitro embryo culture media. Takahashi et al. (2016) studied the addition of the antioxidant N, NDimethylglycine (DMG) in the culture medium and obtained similar results of blastocyst production between treatments with and without supplementation $\quad(57.1 \pm 8.2 \%$ vs $65.0 \pm 5.5 \%$, respectively). On the other hand, Lee et al. (2011) found an increase in blastocyst rate by supplementing the culture medium with 3,4Dihydroxyflavone at $10 \mu \mathrm{M}$ compared to the treatment without this flavonoid $(39.3 \% \mathrm{vs}$. $26.7 \%$, respectively). These studies demonstrate that the direct comparison between different antioxidants in the same embryonic culture protocols has not yet been performed. Consequently, it is difficult to compare and determine the medium that best favors embryo production (Zullo et al., 2016a) because there is great variability between protocols, especially when performed in different laboratories. This variability in response may be due to the 
interference of other factors, such as $\mathrm{O}_{2}$ tension in the incubator, culture medium composition, fetal bovine serum concentration and water quality used in media production (Guerin and Menezo, 2001; Martin-Romero et al., 2008). Some components of these factors increase the formation of ROS, leading to several cellular damages (Rocha-Frigoni et al., 2015).
The apoptotic index and the number of total bovine embryonic cells of blastocysts produced in vitro in media containing different concentrations of oily extract of Lippia origanoides are shown in Table 2.

Table 2. Number of total embryonic cells, inner cell mass (ICM), ICM:total cells and apoptotic cells in bovine blastocyst (B1) produced in vitro, on the seventh day of culture (D7) in media containing different concentrations of essential oils of Lippia origanoides

\begin{tabular}{|c|c|c|c|c|c|c|}
\hline Treatment & $\mathrm{Bl}(\mathrm{n})$ & TE & ICM & $\begin{array}{l}\text { Number of } \\
\text { total cells }\end{array}$ & $\begin{array}{c}\text { ICM:total cells } \\
(\%)\end{array}$ & $\begin{array}{c}\text { Apoptotic } \\
\text { index }\end{array}$ \\
\hline T1 - 0 (Control) & 11 & $123.1 \pm 0.6$ & $40.1 \pm 1.4$ & $163.3 \pm 11.7^{\mathrm{a}}$ & $36.8 \pm 12.3$ & $10.0 \pm 1.4^{\mathrm{a}}$ \\
\hline $\mathrm{T} 2-50 \mu \mathrm{M} / \mathrm{mL}$ Cysteamine & 15 & $91.6 \pm 2.5$ & $39.1 \pm 6.3$ & $130.6 \pm 14.3^{\mathrm{ab}}$ & $47.8 \pm 17.9$ & $4.5 \pm 1.1^{\mathrm{bc}}$ \\
\hline $\begin{array}{c}\mathrm{T} 3-2.5 \mu \mathrm{g} / \mathrm{mL} \text { Lippia } \\
\text { origanoides }\end{array}$ & 9 & $56.1 \pm 1.7$ & $35.3 \pm 9.3$ & $91.4 \pm 7.2^{\mathrm{b}}$ & $57.9 \pm 15.2$ & $8.4 \pm 2.5^{\mathrm{ab}}$ \\
\hline $\begin{array}{c}\mathrm{T} 4-5.0 \mu \mathrm{g} / \mathrm{mL} \text { Lippia } \\
\text { origanoides }\end{array}$ & 14 & $78.1 \pm 3.7$ & $34.2 \pm 13.9$ & $112.3 \pm 9.8^{b}$ & $45.6 \pm 15.2$ & $3.4 \pm 1.1^{\mathrm{c}}$ \\
\hline $\begin{array}{c}\mathrm{T} 5-10.0 \mu \mathrm{g} / \mathrm{mL} \text { Lippia } \\
\text { origanoides }\end{array}$ & 14 & $75.6 \pm 4.2$ & $39.0 \pm 17.8$ & $114.6 \pm 9.6^{\mathrm{b}}$ & $51.0 \pm 17.0$ & $5.5 \pm 0.9^{b c}$ \\
\hline
\end{tabular}

a,b,c Means with different letters in the same column indicate significant differences $(\mathrm{P}<0.05)$ between treatments by Shapiro-Wilk test.

In the present study, the apoptosis rate (Figure 1) of T1 $(10.0 \pm 1.4)$ was similar to T3 $(8.4 \pm 2.5)(\mathrm{P}>$ $0.05)$, but higher than $\mathrm{T} 2(4.5 \pm 1.1), \mathrm{T} 4(3.4 \pm 1.1)$ and T5 $(5.5 \pm 0.9)(\mathrm{P}<0.05)$. On the other hand, $\mathrm{T} 2$ was similar to all treatments $(\mathrm{P}>0.05)$, except to $\mathrm{T} 1(\mathrm{P}<0.05)$. T3 was superior to $\mathrm{T} 4(\mathrm{P}<0.05)$ and similar to other treatments $(\mathrm{P}>0.05)$. T4 was lower than $\mathrm{T} 1$ and $\mathrm{T} 3(\mathrm{P}<0.05)$ and similar to $\mathrm{T} 2$ and T5 $(\mathrm{P}>0.05)$. T5 had a similar apoptosis rate compared to $\mathrm{T} 2, \mathrm{~T} 3$ and $\mathrm{T} 4(\mathrm{P}>0.05)$ and lower than that observed in $\mathrm{T} 1(\mathrm{P}<0.05)$. The total cell number for $\mathrm{T} 1$ was $163.3 \pm 11.7$, higher $(\mathrm{P}<0.05)$ than that found in T3, T4 and T5 (91.4 \pm 7.2 ; $112.4 \pm 9.8,114.6 \pm 9.6$, respectively) but similar (P> 0.05) to $\mathrm{T} 2(130.7 \pm 14.3)$. The total cell number is in accordance with that reported for bovine species, as verified by other studies that also added antioxidants in the in vitro embryo culture medium (Pomar et al., 2005; Sun et al., 2015; Wang et al., 2017).
The values found in the present study are similar to those verified by other research groups that also used antioxidants to supplement the culture media for the in vitro production of bovine embryos. Zullo et al. (2016a,b), testing the antioxidant action of L-ergotionin (amino acid) and crocetin (carotenoid) in the culture of bovine embryos produced in vitro, found no difference in embryo production rates, but a significant reduction in the percentage of apoptotic cells in blastocysts cultured in the presence of Lergotionin in relation to the control group (3.6 $\pm 0.3 \%$ vs. $8.1 \pm 0.5 \%$, respectively). The same was observed between the group supplemented with crocetin and the control group $(3.9 \pm 0.2 \%$ vs. $7.4 \pm 0.3 \%$, respectively). When the enzymatic antioxidant Peroxiredoxin 5 (PRDX5) was inhibited, Wang et al. (2017) found an increase in apoptotic index from $4.2 \pm 0.8 \%$ to $11.9 \pm 2.1 \%$ in blastocysts cultured with and without antiPRDX-5, respectively. 


\section{Sollecito et al.}

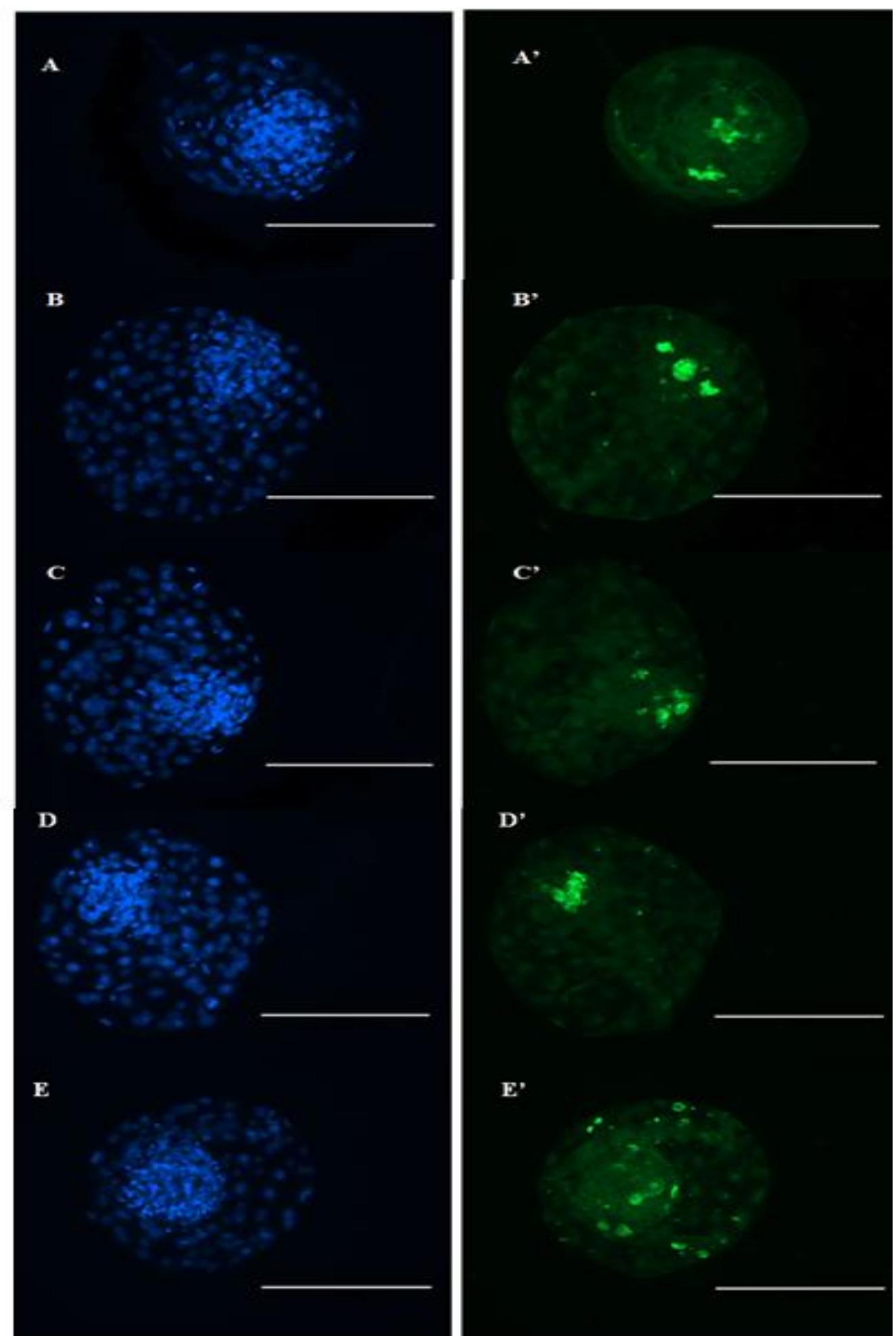

Figure 1. Bovine blastocysts produced in vitro in culture media without supplementation (A and $\mathrm{A}^{\prime}$ ), with supplementation of $50 \mu \mathrm{M} / \mathrm{mL}$ of cysteamine (B and $\left.B^{\prime}\right)$, or with $2.5 \mu \mathrm{g} / \mathrm{mL}\left(\mathrm{C}\right.$ and $\left.\mathrm{C}^{\prime}\right), 5.0 \mu / \mathrm{mL}$ (D and D'), $10 \mu \mathrm{g} / \mathrm{mL}$ (E and E') of antioxidant obtained from oily extract of Lippia origanoides. DAPI-labeled embryonic cells, submitted to the TUNEL test, were visualized by epifluorescence microscopy (blue), and the apoptotic cells were stained by fluorescein (green). Scale bars represent $200 \mu \mathrm{m}$. 
The results found in the present study differ from those obtained by Sun et al. (2015) evaluating the addition of different concentrations of the antioxidant glutathione to the medium $(1,3,5$ and $7 \mathrm{mM}$ ). These authors found no difference in apoptotic index between the control treatment without supplementation $(7.9 \pm 3.1 \%)$ and the other treatments $(6.3 \pm 2.4 \%, 6.5 \pm 3.0 \%, 6.7 \pm 4.1 \%$ and $6.7 \pm 3.5 \%$, respectively).

The apoptosis rate in embryos cultured in vitro is higher than that found in vivo, and this pattern can be seen in all species (Pomar et al., 2005). This demonstrates that in vitro culture leads to a reduction in the number of embryonic cells and, consequently, interferes with the quality of the future embryo. Although apoptosis is a physiological process to eliminate defective cells during the pre-implantation period, the high incidence of apoptosis is correlated with morphological damage that is decisive for embryo survival (Brison, 2000).

In addition to the apoptotic index evaluated by the TUNEL test, the total cell number located in the inner cell mass (ICM) and in trophectoderm (TE) are also commonly used as parameters of embryonic quality (Koo et al., 2002). In the present study, no difference was found in the relationship between ICM:total cell of embryos produced in vitro among the different treatments tested. The data found are similar to those obtained by Salzano et al. (2014) when evaluating the action of resveratrol in the embryo culture medium. These authors also did not verify significant differences in the proportion of ICM:total cells between the blastocysts produced without $(29.1 \pm 1.2)$ or in the presence of $0.5 \mu \mathrm{M}$ resveratrol (31.3 \pm 1.3$)$. However, other studies obtained different results in the proportion of ICM:total cells, which was higher in treatments with antioxidants added to the in vitro culture media (Lee et al., 2011; Zullo et al., 2016a).

In the present study, all treatments had a high ICM:total cell, between 40 and $60 \%$, which demonstrates that the embryos had good quality (Iwasaki et al., 1990) and that this may be an additional criterion to effectively predict the quality of the embryo produced (Pomar et al., 2005). The association of apoptotic index with the reduction in inner cellular mass index (ICM) and in the number of embryonic cells indicates that the non-use or the blockade of antioxidant action negatively affects embryo quality and viability (Wang et al., 2017). This is due to the direct action of antioxidants in the epigenetic process, indirectly controlling gene expression during cell development, altering chromatin structures, DNA methylation and histone modification (Hitchler and Domann, 2007). In addition, ICM cells are known to contribute to the formation of embryonic tissues and extraembryonic membranes, whereas trophectoderm cells are mainly linked to the formation of placental membranes (FouladiNashta et al., 2005).

\section{CONCLUSION}

Supplementation of culture media with antioxidants obtained from Lippia origanoides or standard antioxidant routinely used in in vitro production improves the ratio between number of embryonic cells and apoptotic index, directly affecting embryo quality without increasing the bovine blastocyst production rate, which makes it an alternative to be incorporated in laboratory procedures for in vitro embryo production.

\section{ACKNOWLEDGMENT}

The authors thank Coordenação de Aperfeiçoamento de Pessoal de Nível Superior (CAPES), Fundação de Amparo à Pesquisa do Estado de Minas Gerais (FAPEMIG), Conselho Nacional de Desenvolvimento Científico e Tecnológico $(\mathrm{CNPq})$, and all collaborators for guidance and financial support.

\section{REFERENCES}

AGARWAL, A.; GUPTA, S.; SHARMA, R.K. Role of oxidative stress in female reproduction. Reprod. Biol. Endocrinol., v.3, p.1-21, 2005.

BRISON, D.R. Apoptosis in mammalian preimplantation embryos: regulation by survival factors. Hum. Fertil., v.3, p.36-47, 2000.

CROCOMO, L.F.; MARQUES FILHO, W.C.; LANDIM-ALVARENGA, F.C. et al. Produção de embriões in vitro: estresse oxidativo e antioxidantes. Vet. Zootec., v.19, p.470-479, 2012. 
FEUGANG, J.M.; CAMARGO-RODRIGUEZ, O.; MEMILI, E. Culture systems for bovine embyos. Livest. Sci., v.121, p.141-149, 2009.

FOULADI-NASHTA, A.A.; ALBERIO, R.; KAFI, M. et al. Differential staining combined with TUNEL labeling to detect apoptosis in preimplantation bovine embryos. Reprod. Biol. Med., v.47, p.497-502, 2005.

GUÉRIN, P.; EL MOUATASSIM, S.; MÉNÉZO, Y. Oxidative stress and protection against reactive oxygen species in the preimplantation embryo and its surroundings. Hum. Reprod. Update, v.7, p.175-189, 2001.

HITCHLER, M.J.; DOMANN, F.E. An epigenetic perspective on the free radical theory of development. Free Radic. Biol. Med., v.43, p.1023-1036, 2007.

IWASAKI, S.; YOSHIBA, N.; USHIJIMA, H. et al. Morphology and proportion of inner cell mass of bovine blastocysts fertilized in vitro and in vivo. J. Reprod. Fertil., v.90, p.279-284, 1990.

KIDSON, A.; RUBIO-POMAR, F.J.; VAN KNEGSEL, A. et al. Quality of porcine blastocysts produced in vitro in the presence or absence of GH. Reproduction, v.127, p.165-177, 2004.

KOO, D.B.; KANG, Y.K.; CHOI, Y.H. et al. Aberrant allocations of inner cell mass and trophoectoderm cells in bovine nuclear transfer blastocysts. Biol. Reprod., v.67, p.487-492, 2002.

LEE, K.S.; KIM, E.Y.; JEON, K. et al. 3,4Dihydroxyflavone acts as an antioxidant and antiapoptotic agent to support bovine embryo development in vitro. J. Reprod. Dev., v.57, p.127-134, 2011.

LOIOLA, M.V.G.; CHALHOUB, M.; RODRIGUES, A.S. et al. Validação de um programa de produção in vitro de embriões bovinos com transporte de oócitos e de embriões por longas distâncias. Ciên. Anim. Bras., v.15, p.93-101, 2014.

LOJKIC, M.; GETZ, I.; SAMARDZIJA, M. et al. Effect of cysteamine supplementation during in vitro culture of early stage bovine embryos on blastocyst rate and quality. Acta. Vet., p.229-234, 2012.

LONERGAN, P.; FAIR, T. In vitro produced bovine embryos - dealing with the warts. Theriogenology, v.69, p.17-22, 2008.
MADDOX-HYTTELL, P.; GJORRET, J.O.; VAJTA, G. et al. Morphological assessment of preimplantation embryo quality in cattle. Reprod. Suppl., v.61, p.103-106, 2003.

MARTIN-ROMERO, F.J.; MIGUELLASOBRAS, E.M.; DOMINGUEZ-ARROYO, J.A. et al. Contribution of culture medium to oxidative stress and its effects on human oocytes. Reprod. Biomed., v.17, p.652-661, 2008.

MERTON, J.S.; KNIJN, H.M.; FLAPPER, H. et al. Cysteamine supplementation during in vitro maturation of slaughterhouse and opu-derived bovine oocytes improves embryonic development without affecting cryotolerance, pregnancy rate and calf characteristics. Theriogenology, v.80, p.365-371, 2013.

PARRISH, J.J.; PARRISH, J.L.; FIRST, N.L. Effect of swim-up separation and heparin pre treatment of frozen-thawed spermatozoa on in vitro fertilization of bovine oocytes. Biol. Reprod., v.30, Suppl.1, p.112, 1984.

PEREIRA, E.C.M. Produção de oócitos $e$ embriões bubalinos: efeitos da época do ano e da adição de óleo essencial de Lippia origanoides na maturação in vitro. 2015. 128f. Tese (Doutorado em Biotecnologia Animal) Faculdade de Medicina Veterinária e Zootecnia, Universidade Estadual Paulista, Júlio de Mesquita Filho, Botucatu, SP.

PEREIRA, M. M. Efeito de diferentes sistemas de maturação in vitro no potencial de desenvolvimento de oócitos bovinos. 2010. 75 f. Dissertação (Mestrado em Ciências Biológicas) Universidade Federal De Juiz De Fora (UFJF), MG.

POMAR, F.J.R.; TEERDS, K.J.; KIDSON, A. et al. Differences in the incidence of apoptosis between in vivo and in vitro produced blastocysts of farm animal species: a comparative study. Theriogenology, v.63, p.2254-2268, 2005.

ROCHA-FRIGONI, N.A.S.; LEÃO, B.C.S.; NOGUEIRA, E. et al. Effect of gaseous atmosphere and antioxidants on the development and cryotolerance of bovine embryos at different periods of in vitro culture. Zygote, v.23, p.159168, 2015. 
SALZANO, A.; ALBERTO, G.; ZULLO, G. et al. Effect of resveratrol supplementation during culture on the quality and cryotolerance of bovine in vitro produced embryos. Anim. Reprod. Sci., v.151, p.91-96, 2014.

SENEDA, M.M., ESPER, C.R., GARCIA, J.M., OLIVEIRA, J.A., VANTINI, R. Relationship between follicle size and ultrasound-guided transvaginal oocyte recovery. Anim. Reprod. Sci., v.67, p.37-43, 2001.

SOARES, B.V.; TAVARES-DIAS, M. Espécies de Lippia (Verbenaceae), seu potencial bioativo e importância na medicina veterinária e aquicultura. Biota Amazônia, v.3, p.109-123, 2013.

SUN, W-J.; PANG, Y.W.; LIU, Y. et al. Exogenous glutathione supplementation in culture medium improves the bovine embryo development after in vitro fertilization. Theriogenology, v.84, p.716-723, 2015.

TAKAHASHI, T.; SASAKI, K.; SOMFAI, T. et al. N, N-Dimethylglycine decreases oxidative stress and improves in vitro development of bovine embryos. J. Reprod. Dev., v.62, p.209$212,2016$.
TEIXEIRA, M.L.; CARDOSO, M.G.; FIGUEIREDO, A.C.S. et al. Essential oils from Lippia origanoides Kunth. and Mentha spicata L: chemical composition, insecticidal and antioxidant activities. Am. J. Plant Sci., v.5, p.1181-1190, 2014.

WANG, L.; ZHANG, H.; WANG, Y. et al. Peroxiredoxin 5 is essential for in vitro development of bovine SCNT embryos. Theriogenology, p.156-166, 2017.

ZHOU, P.; WU, Y.G.; LI, Q. et al. The interactions between cysteamine, cystine and cumulus cells increase the intracellular glutathione level and developmental capacity of goat cumulus-denuded oocytes. Reproduction, v.135, p.605-611, 2008.

ZULlO, G.; ALBERO, G.; NEGLIA, G. et al. L-ergothioneine suplementation during culture improves quality of bovine in vitro-produced embryos. Theriogenology, v.85, p.688-697, 2016 a.

ZULLO, G.; De GANDITIIS, C.; PERO, M.E. et al. Crocetin improves the quality of in vitroproduced bovine embryos: Implications for blastocyst development, cryotolerance, and apoptosis. Theriogenology, v.86, p.1879-1885, 2016 b. 